logos_i_ethos_2017_(45)_numer specjalny, s. 105-122

DOI: http://dx.doi.org/10.15633/lie.2340

Paulina Mendeluk

Uniwersytet im. Adama Mickiewicza w Poznaniu

\title{
Wady i zalety common sense w wyjaśnianiu i rozumieniu świata społecznego
}

W perspektywie filozoficznej pojęcia rozumu i rozsądku mają różne desygnaty. Pojęcie rozumu często poddawane jest rozważaniom filozoficznym. Natomiast sfera rozsądkowa jest często $w$ nich marginalizowana. Na ogół filozofowie starają się uniknąć dysputy na temat zdrowego rozsądku, traktując go w kategoriach wiedzy potocznej, która w ich odczuciu jest mniej wartościowa oraz mniej przydatna. Taki stan rzeczy spowodowany jest przede wszystkim tym,

Paulina Mendeluk - doktorantka w Zakładzie Filozofii Społecznej i Politycznej Instytutu Filozofii Uniwersytetu im. Adama Mickiewicza w Poznaniu. Najważniejsze publikacje: Problem zaufania $w$ kontekście „skomercjalizowanej i konsumpcyjnej" rzeczywistości społecznej, w: Zaufanie w życiu publicznym, red. W. Zuziak, J. Mysona Byrska, Kraków 2014, s. 103-125; Problem autonomii podmiotu politycznego w trzech modelach demokracji, „Filo-Sofija” 15 (2015) nr 29 (2/I), red. L. Godek, M. Sikora, s. 149-165. Jej zainteresowania naukowe koncentrują się wokół filozofii społecznej i politycznej, filozofii prawa oraz etyki. że pojęcie zdrowego rozsądku jest bliżej niesprecyzowane, a więc ciężko uchwycić jego istotę i odróżnić je chociażby od potocznego zastosowania takich terminów, jak: sensowność czy też racjonalność. Ambiwalentny stosunek do zdrowego rozsądku rodzi się z przeświadczenia, że jest on przeciwieństwem filozofii ${ }^{1}$. Czym zatem jest ów zdrowy rozsądek?

Stefan Zabieglik jako przedmiot swoich badań przyjął pojęcie zdrowego rozsądku i spostrzegł, że jego znaczenie w języku polskim nie przekłada się na powszechnie przyjęte identyfikowanie go z terminem common sense wywodzącym się z języka angielskiego. Zabieglik wskazuje, że common

1 M. Rozynek, Kilka uwag o pojęciu zdrowego rozsądku w perspektywie filozofii politycznej, „Mishellanea” 2004 nr 4, s. 1. 
sense w dosłownym tłumaczeniu oznacza „pospolity rozsądek”, natomiast odpowiednikiem „zdrowego rozsądku” jest termin good sense. Oznacza to, że pojęcie common sense - podobnie jak pojęcie „zdrowy rozsądek” niełatwo zdefiniować i umieścić w jakieś ramy myślowe. Trudność ta ujawnia się zwłaszcza w kontekście rozważań filozoficznych ${ }^{2}$. Bardzo często zdrowy rozsądek, oprócz wspomnianej już wiedzy potocznej, utożsamiany jest $z$ takimi pojęciami, jak poznanie naiwne, wiedza przednaukowa, myśl potoczna, wiedza codzienna bądź racjonalność społeczna.

Domeną filozofii jest krytycyzm, który jest procesem ciągłym, gdyż można cały czas go udoskonalać i rozpoczynać na nowo, przyjmując inny punkt odniesienia. Myślenie zdroworozsądkowe natomiast stwarza człowiekowi poczucie stabilności oraz bezpieczeństwa dla jego własnej egzystencji. Myślenie zdroworozsądkowe określa się także mianem myślenia potocznego, które jest silnie związane z kategorią common sense. $\mathrm{W}$ jego obrębie mamy tutaj do czynienia $\mathrm{z}$ działaniem oraz poznaniem przednaukowym. Wiedza zdroworozsądkowa budowana jest za pomocą przekonań intuicyjnych, doświadczeń oraz doznań jednostkowych. Jest ona odpowiednikiem „bycia w świecie” w ujęciu Heideggerowskim ${ }^{3}$.

Filozofowanie rozumie się w kategorii aktywności intelektualnej zmierzającej ku poznaniu. Jest to nietypowa forma rozumowania. W refleksji filozoficznej punktem wyjścia jest często postawienie pytań, na które staramy się uzyskać odpowiedzi. Tego typu rozumowanie możemy określić mianem myślenia problemowego, a zatem płodnego i twórczego. Zainicjowanie procesu myślowego, a więc namysłu nad daną kwestią, może okazać się bardziej rozwojowe, niż osiągnięcie odpowiedzi, bo te mogą okazać się tylko dezaktualizacją pytania, które postawiliśmy ${ }^{4}$.

W odniesieniu do common sense, czyli wiedzy zdroworozsądkowej filozofia nie zajmuje tak naprawdę jednoznacznego stanowiska. Z jednej strony przyjmuje się, że wiedza poznawcza wypływająca $z$ naszego doświadczenia wspiera namysł filozoficzny, albowiem pozwala uchwycić

2 M. Rozynek, Kilka uwag o pojęciu zdrowego rozsądku..., dz. cyt., s. 1-2.

3 A. Karpiński, J. Kojkoł, Filozofia, zarys historii, Gdynia 2001, s. 9.

4 A. Pobojewska, Co to znaczy filozofować?, „, Analiza i Egzystencja” 15 (2011), s. 100-102. 
sposób rozumowania, który obecny jest w naszym życiu ${ }^{5}$. Z drugiej strony poddaje common sense ostrej krytyce, wskazując na jego schematyczność oraz praktyczność, która nie sprzyja rozwojowi intelektualnemu.

\section{Common sense jako zagrożenie dla myśli oraz refleksji politycznej}

W tym momencie warto wskazać niektóre koncepcje filozoficzne kwestionujące wartość natury oraz krytykujące specyfikę myślenia potocznego. Angielski filozof Francis Bacon w swoich rozważaniach stwierdził, że umysł ludzki ma tendencje do popełniania błędów, albowiem dąży do zaspokojenia swych przyjemności ${ }^{6}$. Uważał, że myślenie potoczne może nas zaprowadzić tylko do świata „mamideł”. Bacon uznawany jest za twórcę „koncepcji idoli”, wyróżnił ich cztery typy: idole plemienia, jaskini, rynku oraz teatru. Wedle niego wszystkie z nich należy traktować jako przeszkody, które ograniczają człowieka w drodze do osiągnięcia prawdziwego poznania, czyli wiedzy naukowej. Zdaniem Bacona „idole plemienia” są przyczyną złudnego poznawania rzeczywistości, ponieważ są tworem wywodzącym się z naturalnych skłonności ludzkiego umysłu. Oznacza to, że na bazie owych złudzeń budujemy mylną perspektywę świata, gdyż jest ona ujmowana wyłącznie z punktu widzenia jednostki nie zaś wszechświata. W samym procesie poznawczym pojawia się wyraźne oddziaływanie woli oraz uczuć. Mamy tutaj do czynienia z przewartościowaniem wiedzy zmysłowej. W przypadku „idoli jaskini” złudzenia czerpią swoje źródło z indywidualnych predyspozycji podmiotu poznającego, czyli jego cech jednostkowych. To znaczy, że każdy człowiek odbiera świat przez pryzmat osobistej jaskini, czyli na podstawie swych umiejętności, nawyków czy środowiska. W tym znaczeniu indywidualna skłonność popełniania błędów przez człowieka jest ściśle związana z jego

5 J. Jusiak, Filozofia w Wielkiej Brytanii. Cechy szczególne i główne tendencje myślowe, w: Duch filozofii, red. H. Jakuszko, J. Mizińska, Lublin 2004, s. 60 (Lubelskie Odczyty Filozoficzne, 9).

6 M. Grabowska, Potoczność w obrazie wiary w Boga na podstawie wypowiedzi wspótczesnych Polaków, „Słowo. Studia językoznawcze” 2014 nr 5, s. 69. 
temperamentem oraz wychowaniem. Z kolei „idole rynku” tworzone są za pośrednictwem niewłaściwie sformułowanych pojęć, niemających odzwierciedlenia w rzeczywistości. Pojawią się tu także wieloznaczności językowe, które mogą powstać w wyniku mylnego wyabstrahowania danych terminów. Natomiast u Bacona „idole teatru” należy identyfikować z błędami teoriopoznawczymi, które występują w poszczególnych systemach filozoficznych ${ }^{7}$.

Według Bacona wydobyć nas z tego świata „mamidel” może jedynie filozofia, która posiada inspirujący wpływ na rozwój nauki. Podobny pogląd podzielał David Hume, który nie uznawał wiedzy zdroworozsądkowej, wskazując, że nie posiada ona żadnej metody i jest wyzbyta z wszelkich przejawów krytycyzmu. Postrzegał on przekonania zdroworozsądkowe jako ograniczenia przeszkadzające w osiągnięciu racjonalnego poznania ${ }^{8}$.

Na polskim gruncie krytykę zdrowego rozsądku podjęła współczesna filozof Teresa Hołówka. W swoich rozważaniach określa „zdrowy rozsądek" jako zbiór bezrefleksyjnych przeświadczeń. Na ich podstawie niemożliwe jest zbudowanie spójnego światopoglądu, bo są one wyłącznie katalogiem wielu odmiennych spostrzeżeń oraz idei. Spoiwem dla tych bezrefleksyjnych przeświadczeń mogą okazać się wspólne preferencje społeczne. Według Hołówki źródłem ich istnienia jest ludzka skłonność do ulegania społecznym autorytetom. Kierowanie się wiedzą zdroworozsądkową ściśle wiąże się z pragnieniem asymilacji wszystkiego, co znajduje się w obrębie naszej partycypacji. Myślenie potoczne zatem nie może stać się nośnikiem zasad duchowych, które mają obowiązywać w danym społeczeństwie. Tym bardziej nie ma sensu za jego pośrednictwem poszukiwać fundamentalnych reguł dla panującej władzy politycznej9

Kierując się zdrowym rozsądkiem w sferze życia publicznego, koncentrujemy swoją uwagę na krótkotrwałych celach. Ważne staje się tu

7 S. Czerniak, Gernota Böhmego idea końca ery Baconiańskiej, „Filozofia i Nauka” 1 (2013), s. $43-44$.

8 M. Grabowska, Potoczność w obrazie wiary..., dz. cyt., s. 69-70.

9 A. Malewska-Szałygin, Zarys tradycji stosowania pojęcia „wiedza potoczna”, „Etnografia Polska” 39 (1995) z. 1-2, s. 60. 
i teraz, to znaczy, że w procesie podejmowania decyzji nie uwzględniamy ich dalszych konsekwencji. Dlatego też zdrowy rozsądek konotuje współwystępowanie etyki sytuacyjnej. Etyka sytuacyjna odnosi się do postawy jednostki bądź grupy, która dokonuje swobodnego wyboru, nie biorąc pod rozwagę żadnych obiektywnych preferencji oraz osądów. Przez to stara się zamanifestować swoje własne ,ja" ${ }^{\prime 10}$.

W odniesieniu do sfery politycznej kierowanie się etyką sytuacyjną może doprowadzić do absolutyzacji aktu decyzyjnego przez władzę polityczną. Innymi słowy, rządzący będą swoje działania legitymizować teraźniejszą sytuacją, a to może doprowadzić do przykrych konsekwencji w przyszłości. Będą więc dokonywać działań politycznych w oparciu o własną, subiektywną ocenę zastanej rzeczywistości społeczno-politycznej. To znaczy, że rządzący przejmą inicjatywę działania w imieniu wszystkich obywateli. Na podobnych zasadach działa zdrowy rozsądek, ponieważ nie dokonuje on refleksji, a więc nie jest w stanie wyciągnąć samodzielnych wniosków. Oznacza to, że swoje działanie przyjmuję za jedyne słuszne i właściwe w danej sytuacji ${ }^{11}$.

Przeciwnicy common sense uznają, że działania oparte tylko na wiedzy zdroworozsądkowej nie są wystarczające, szczególnie w odniesieniu do perspektywy politycznej. Wynika to $\mathrm{z}$ tego, że są one pozbawione uzasadnienia aksjologicznego, ponieważ kierują się czystym pragmatyzmem. Pragmatyzm ten odarty jest z namysłu oraz wszelkiej refleksji filozoficznej. Współczesna forma uprawiania polityki zmaga się z problemem dominacji irracjonalnych działań. To znaczy, że najpierw władza polityczna podejmuje określone działanie, a dopiero później zastanawia się nad jego konsekwencjami. Przedstawiciele władzy politycznej formułują swoje obietnice w taki sposób, by wzbudzić pożądane emocje. Innymi słowy, budują swą narrację w oparciu o utrwalone społecznie stereotypy, które są domeną myślenia powszechnego, pozbawionego racjonalnego namysłu ${ }^{12}$.

10 T. M. Jaroszewski, Filozofia egzystencji a etyka sytuacyjna Jean Paul Sartre’a, „Etyka” 7 (1970), s. 62.

11 T. M. Jaroszewski, Filozofia egzystencji..., dz. cyt., s. 62-63.

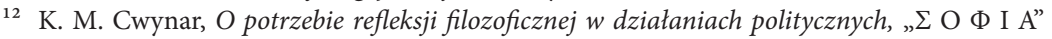
15 (2015), s. 274. 
Chodzi zatem o "mamienie” obywateli, a nie wypełnienie przez polityka swoich obowiązków. Przykładowo, powoływanie się na hasła narodowe przez przedstawicieli władz ma na celu ugruntować i umocnić w świadomości społecznej wyjątkowość narodową, co w rezultacie może zaprowadzić nas do nacjonalizmu. W ten sposób działania polityczne są legitymizowane poprzez emocję czy też wiarę, co może stworzyć poważne zagrożenie w postaci braku tolerancji, dyskryminacji i wywołać falę przemocy ${ }^{13}$.

Przeciwnicy wiedzy zdroworozsądkowej odwołują się do zasadnego przekonania, że działanie jednostki bądź danej grupy wynika z jej sposobu myślenia. Sposób myślenia danej zbiorowości staje się determinantą dla funkcjonowania różnych sfer życia społecznego, do której przynależy wspomniana już sfera polityki. Dostrzegają oni niebezpieczeństwo w myśleniu inspirowanym potocznością, które opiera się na stereotypach, emocjach, wierzeniach religijnych funkcjonujących w ramach danego społeczeństwa ${ }^{14}$. Common sense pozbawiony jest refleksyjności, która umożliwia precyzyjną interpretację zjawisk społecznych. Predyspozycją myślenia potocznego jest wytwarzanie poczucia bezpieczeństwa i stabilizacji u obywateli danej wspólnoty. Te elementy sprawiają, że człowiek zyskuje złudne wrażenie, że sprawuje kontrolę nad własnym życiem. Wiedza powszechna ugruntowana jest na prostych schematach interpretacyjnych, które zyskują powszechną aprobatę społeczeństwa. Dlatego też pochopnie przypisujemy jej miano słusznej oraz obiektywnej. Innymi słowy, nie potrafimy dostrzec, że prowadzi ona de facto do trywializacji znaczeń występujących w świecie zjawisk ${ }^{15}$.

Przeciwnicy common sense wysunęli z tego wniosek, że to myślenie filozoficzne powinno odpowiadać za kształtowanie oraz funkcjonowanie sfery politycznej, nie zaś myślenie powszechne, zdroworozsądkowe. Argumentują to tym, że idee formułowane przez filozofów niejednokrotnie ujawniały swoje odzwierciedlenie w politycznej praktyce. Współ-

13 K. M. Cwynar, O potrzebie refleksji filozoficznej..., dz. cyt., s. 274-275.

14 K. M. Cwynar, O potrzebie refleksji filozoficznej..., dz. cyt., s. 275.

15 A. Malewska-Szałygin, Zarys tradycji stosowania pojęcia „wiedza potoczna”, dz. cyt., s. 60. 
cześnie coraz częściej dostrzegamy, że działania polityczne koncentrują się wyłącznie na rozwiązywaniu bieżących problemów, a więc są krótkofalowe. Stanowi to zagrożenie dla życia społecznego, bo nie podejmujemy wysiłku, aby przewidzieć ich dalekosiężne konsekwencje. Za taki stan rzeczy odpowiada myślenie pragmatyczne, które nastawione jest przede wszystkim na działanie, a nie na refleksję. Oznacza to, że odrzuca się tu wymiar transcendentalny, gdzie występują idee oraz wartości wyższe, na rzecz krótkofalowych rozwiązań. Nadrzędna staje się zatem sama kategoria użyteczności, w której bagatelizuje się rozważania natury etycznej oraz filozoficznej. Rodzi to poważne problemy społeczne, jak nihilizm, konsumpcjonizm, które bezpośrednio zagrażają myśleniu refleksyjnemu, ale i prawidłowemu funkcjonowaniu każdej sfery życia człowieka, w tym również sfery politycznej. Marginalizowana jest rola rozumowania racjonalnego, refleksyjnego na rzecz pragmatycznej wizji świata. Powoduje to, że ograniczamy swoje jestestwo do tego, co w danej chwili przynosi nam codzienność. Współcześnie to środki masowego przekazu stają się nośnikiem pragmatycznych wartości, gdzie sprowadza się egzystencję człowieka do zaspokajania pragnień, a więc takiego stylu życia, który pozbawiony jest wysiłku intelektualnego ${ }^{16}$.

Nie można całkowicie odrzucić znaczenia sfery emocjonalnej u człowieka oraz działań praktycznych. Jednakże dominacja pragmatyzmu oraz irracjonalizmu sprzyja rozwijaniu się wartości antyhumanistycznych w każdym wymiarze życia społecznego. Wówczas mamy do czynienia ze zjawiskami przemocy oraz dyskryminacji. Innymi słowy, każdego zaczynamy traktować w kategoriach konkurenta, bądź wroga. Ten typ postrzegania drugiego człowieka powstaje $\mathrm{w}$ wyniku wspomnianego pragmatyzmu i irracjonalności. Dlatego też poskromić żądze pragmatyzmu, jak i zwalczyć negatywne skutki działań emocjonalnych może tylko i wyłącznie roztropność, która jest fundamentalna dla myślenia filozoficznego ${ }^{17}$.

16 K. M. Cwynar, O potrzebie refleksji filozoficznej..., dz. cyt., s. 275-277.

17 K. M. Cwynar, O potrzebie refleksji filozoficznej..., dz. cyt., s. 277. 


\section{Common sense jako fundament tożsamości jednostki w danym kręgu kulturowym}

Zdrowego rozsąadku bronił George Berkeley. W jego filozofii pojęcie zdrowego rozsądku można ujmować w kategoriach dyspozycji ${ }^{18}$. Świadczy o tym myśl zawarta w Dialogu III: „wreszcie, czy zważywszy przesłanki powyższe, nie będzie rzeczą najmądrzejszą iść za wskazaniem natury, dowierzać własnym zmysłom, wyzbyć się wszelkich niepokojących myśli o nieznanych naturach czy substancjach i uznać wraz z ogółem za realne te rzeczy, które postrzegamy zmysłami?"19. Wynika z tego, że człowiek powinien kierować się w życiu naturalną dyspozycją, czyli zdrowym rozsądkiem, bo tylko jemu jest w stanie w pełni zaufać. Kierowanie się zdrowym rozsądkiem umożliwia jednostce, $w$ tym także wspólnocie tworzenie i ustalanie obowiązujących w świecie przekonań. Zdaniem Berkeleya jednostka obdarzona common sense posiada zdolność stawiania zdroworozsądkowych sądów niespaczonych uprzednim wykształceniem. Oznacza to, że wykształcenie, zwłaszcza filozoficzne ogranicza zdroworozsądkowe podejście, gdyż zostaje one przysłonięte wątpliwościami rodzącymi się z nadmiernej „uczoności” 20 .

Jednostka podążająca za zasadą common sense zawierza swoim zmysłom. W związku z powyższym kieruje się przeświadczeniem, że wszystkie obiekty materialne, które ma możliwość zobaczyć oraz poczuć za pomocą zmysłów, to przedmioty realnie istniejące. Zdobywa zatem pewność zarówno istnienia rzeczy, jak i własnego jestestwa. Dlatego też bezpośrednie postrzeganie rzeczywistości, która nas otacza, legitymizuje istnienie twierdzeń zdroworozsądkowych ${ }^{21}$.

Berkeley jest zatem przeciwnikiem wszelkich idei abstrakcyjnych, uznając je za niemożliwe do udowodnienia, a więc sprzeczne ze zdrowym rozsądkiem. Odrzuca również materializm, który zakłada istnienie

18 D. Kucharski, „Common sense” jako uzasadnienie Berkeleyowskiej tezy immaterialistycznej, „Studia Philosophiae Christianae" 48 (2012) nr 2, s. 55.

19 D. Kucharski, „Common sense” jako uzasadnienie..., dz. cyt., s. 55.

20 D. Kucharski, „Common sense” jako uzasadnienie..., dz. cyt., s. 56.

21 D. Kucharski, „Common sense” jako uzasadnienie..., dz. cyt., s. 56-58. 
niematerialnych umysłów oraz materialnych przedmiotów. Obiekty materialne mogą istnieć w pełni niezależnie od umysłu. W tym kontekście uznaje, że fizyczne przedmioty nie są materialnymi przedmiotami, ponieważ samo pojęcie materii należy traktować w kategoriach fikcji filozoficznej. Ma ona nas zaprowadzić do podważenia wiary we własne zmysły, czyli wiedzę opartą na poznaniu zmysłowym. Koncepcja Berkeleya wskazuje na znaczenie zmysłów, gdyż dzięki nim człowiek ma możliwość poznania świata zewnętrznego. Natomiast bezpośrednim przedmiotem dla zmysłów są tylko i wyłącznie idee zmysłowe, a więc te, które nie posiadają podłoża materialnego. Tym, co stanowi sens ich istnienia, jest tak zwana substancja duchowa, nie zaś jak starali się przekonywać zwolennicy materializmu - substancja materialna ${ }^{22}$.

Z innej perspektywy bronił zdrowego rozsądku przedstawiciel szkoły szkockiej Thomas Reid. Uważał, że wiedza zdroworozsądkowa powinna być traktowana jako punkt wyjścia dla wszelkich rozważań filozoficznych. W przypadku, gdy wiedza filozoficzna stoi w opozycji do wiedzy zdroworozsądkowej, należy ją z gruntu uznać za fałszywą. Dlatego też common sense powinien stanowić fundament dla wszelkich dociekań natury filozoficznej. Wedle Reida poglądy zdroworozsądkowe stanowią budulec aparatu poznawczego wywodzącego się z naszej pierwotnej natury. Nie powinno się ich zatem w żadnym stopniu bagatelizować i zakładać, że są błędne. Przeświadczenia zdroworozsądkowe postrzega on w kategoriach pierwotnych prawd, na bazie których budujemy swoje życiowe doświadczenie. Zdaniem Reida o silnej pozycji wiedzy zdroworozsądkowej przesądza fakt, że jest ona powszechnie akceptowana oraz uznawana za oczywistą. Założenia zdroworozsądkowe nie wymagają więc jakiegokolwiek dowodu potwierdzającego ich wiarygodność, gdyż nie istnieją pewniejsze od nich przesłanki ${ }^{23}$. Ludzkie poznanie według Reida opiera się na takich założeniach, których nie jesteśmy w stanie dowieść. Uważa, że to czynnik decydujący o sile naszego poznania, nie zaś o jego

22 D. Kucharski, „Common sense” jako uzasadnienie..., dz. cyt., s. 58-61.

23 P. Mrzygłód, Jaka filozofia na dzisiejsze czasy...? Postmodernizm?, „Perspectiva” 11 (2012) nr 2, s. 124-125. 
słabości, dlatego że posiadamy zdolność ich zrozumienia i umiejętnie je odczytujemy. Podstawowe prawdy, których nie jesteśmy w stanie dowieść, określa mianem zasad zdrowego rozsądku. Ludzie korzystają z tych zasad w codziennym życiu i należy je uwzględniać w namyśle filozoficznym, a nie dążyć do ich eliminacji. Uznawał, że sądy powszechne czerpią swoje źródło ze zdroworozsądkowych spostrzeżeń, które należy traktować w kategoriach wspólnego zamysłu ${ }^{24}$.

Podobnie rozumował Charles Sanders Peirce, wskazując, że poznanie zdroworozsądkowe stanowi warunek konieczny dla wszystkich innych form poznawczych człowieka. Zdaniem Peirce’a od spostrzeżeń zmysłowych, które umożliwiają bezpośredni kontakt z rzeczywistością, wywodzi się wszelkie poznanie. Przypisywał on zatem ogromną rolę wiedzy empirycznej. W przeciwieństwie do Reida nie uważał, że posiadamy jakieś "odgórne" pierwotne prawdy, których źródłem jest nasza ludzka natura. Jego zdaniem bez doznań zmysłowych nie możemy mówić o ludzkim poznaniu, ponieważ to dzięki nim umysł ludzki zaczyna uruchamiać poznanie intelektualne. Z poznaniem intelektualnym mamy do czynienia wówczas, gdy dokonamy ujęcia treści doznania empirycznego w sąd postrzeżeniowy, który zależny jest od danego spostrzeżenia, a nie od jakichkolwiek rozważań. Wedle Peirce’a owe sądy postrzeżeniowe wyrażają wiedzę wywodzącą się z naszych bezpośrednich spostrzeżeń. To znaczy, że dają one nam ogląd, czego w danym momencie doświadczyliśmy, bez względu na to, co dokładnie miało miejsce. Ludzki umysł formułuje sądy postrzeżeniowe w sposób automatyczny, tym samym nadając określonemu spostrzeżeniu informację dotyczącą jego treści, którą uznajemy za pewną. Sądy te, dokonując ujęć danych zmysłowych, nadają pierwotną podstawę dla wszelkich innych form rozumowań. Oznacza to, że na ich podstawie możemy coś zakładać, przewidywać i w rezultacie wyciągnąć określone wnioski. Innymi słowy, sądy postrzeżeniowe są naszymi pierwszymi przesłankami, dzięki którym mamy możliwość budowania sądów i hipotez zyskujących w końcu miano naszych przekonań. Przekonanie

24 P. Gutowski, O trzech elementach filozofii Thomasa Reida, „Roczniki Filozoficzne” 58 (2010) nr 1, s. 80-84. 
zdaniem Preice’a należy rozumieć jako formę potwierdzającą prawdziwość danego sądu. Tymczasem stan wątpienia to stan, w którym stawiamy pytania odnośnie do jego prawdziwości. Według tego filozofa sądy postrzeżeniowe stanowią punkt wyjścia dla zdziwienia człowieka, co wzmaga w nim proces formułowania i tworzenia różnorodnych pytań o naturze filozoficznej. W związku z powyższym wiedza zdroworozsądkowa, której źródłem są doznania zmysłowe, jest niezbędna do tego, aby móc rozpocząć wszelkie rozważania intelektualne ${ }^{25}$.

Za przykład może posłużyć sytuacja, w której obywatele dokonują aktu wyborczego tylko w oparciu o zdroworozsądkowe rozumowanie. To znaczy, że traktują go w kategorii obowiązku społecznego, czyli czegoś, co należy spełnić. Natomiast $\mathrm{w}$ momencie, gdy podejmą próbę zastanowienia się nad dokonanym przez siebie wyborem, mówimy o rozumowaniu intelektualnym, gdyż wybór poddany jest refleksji. Różnica polega na tym, że rozumowanie rozsądkowe koncentruje się na samym akcie działania. To znaczy, że biorę udział w wyborach, bo umożliwiła mi to dana sytuacja. Natomiast dokonywanie oceny swojego wyboru i wyciąganie samodzielnych wniosków to namysł intelektualny.

Innym współczesnym myślicielem opowiadającym się za zdrowym rozsądkiem jest Clifford Geertz, twórca antropologicznej wykładni common sense ${ }^{26}$. Wiedzę zdroworozsądkową postrzega w kategoriach zamysłu wspólnotowego. Myśl powszechną traktuje jako swego rodzaju uniwersum interpretacyjne. W jego obrębie dochodzi do uchwycenia znaczeń oraz wartości. Wiedza zdroworozsądkowa wedle Geertza wynika z naszego doświadczenia, a więc nie jest zakorzeniona w naszej naturze ${ }^{27}$.

Zdaniem Geertza zdrowy rozsądek charakteryzuje się pięcioma właściwościami, takimi jak: naturalność, praktyczność, niemetodycznych oraz dostępność. Naturalność rozumie jako cechę konstytuującą wiedzę wspólnotową opierającą się na rozsądku. Nie wymaga ona żadnego

25 P. Broszkiewicz, Charlesa Sandersa Peirce’a koncepcja znaku względem Peirce’owskiego pragmatyzmu, „Słupskie Studia Filozoficzne” 2012 nr 11, s. 191-193.

26 J. Szewczyk-Kowalczyk, Mistyfikacja codzienności szkolnej, czyli refleksji kilka o „common sense” szkoły, „Studia Pedagogiczne” 64 (2011), s. 73.

27 J. Szewczyk-Kowalczyk, Mistyfikacja codzienności szkolnej..., dz. cyt., s. 74. 
uzasadnienia, albowiem w obrębie danej kultury posiada status oczywistej. Wyraża się w przedstawianiu naturalnych procesów życia codziennego i związanych $\mathrm{z}$ nimi zjawisk w możliwie jak najprostszy sposób. Z kolei praktyczność Geertz identyfikował z roztropnością wywodzącą się z mądrości ludowej. Jest ona nośnikiem praktycznych wskazówek, którymi powinniśmy się kierować w życiu. Trzecią własnością jest przezroczystość, którą myśliciel utożsamiał z umiejętnością zdroworozsądkowego oglądu określonej sytuacji. Innymi słowy, ze zdolnością przedstawienia danych spraw w sposób dosłowny oraz klarowny, unikając przy tym nadinterpretacji powstałej w wyniku myślenia abstrakcyjnego. Niemetodyczność pojmował jako odwołanie się do wiedzy zdroworozsądkowej ugruntowanej kulturowo, bez uwzględnienia naukowego kontekstu oraz intelektualnych dyskursów. Z kolei dostępność należy jego zdaniem traktować jako logiczną konsekwencję wcześniejszych uwarunkowań common sense. Dostępność uznawał za swego rodzaju założenie o tym, że każda racjonalnie myśląca jednostka posiada zdolność uchwycenia zdroworozsądkowych wniosków, które powinny być przez nią zrozumiałe oraz zaakceptowane. Wiedza zdroworozsądkowa jest zatem wiedzą dostępną wszystkim i stanowi powszechną własność. To znaczy, że zwykły człowiek umiejętnie odnajduje się w świecie myślenia potocznego obowiązującego $\mathrm{w}$ danym kręgu kulturowym ${ }^{28}$.

W ujęciu Geertza wiedza zdroworozsądkowa stanowi podstawę dla wszelkich innych form rozumowania. Myśl powszechna wywodząca się ze zdrowego rozsądku jest intersubiektywna, ponieważ powstaje w wyniku interakcji ludzi będących uczestnikami danej kultury semiotycznej ${ }^{29}$. W związku z powyższym wiedzę powszechną zaczynamy poznawać już $\mathrm{w}$ procesie socjalizacji.

Zwolennicy common sense nie zgodzą się z założeniem, że wiedza zdroworozsądkowa jest mniej wartościowa od wiedzy naukowej, filozoficznej.

28 C. Geetz, Wiedza lokalna. Dalsze eseje z zakresu antropologii interpretatywnej, Kraków 2005, s. 93-99.

29 J. Szewczyk-Kowalczyk, Indywidualne doświadczenie, wspólnotowy sens i zdroworozsądkowa myśl potoczna w kontekście koncepcji „common sense”, „Kultura i Wychowanie” 2011 nr 1, s. 245-246. 
Wskazują oni, że w świecie obowiązują dwa sposoby myślenia, myślenie zdroworozsądkowe oraz myślenie naukowe. Nie oznacza to jednak, że nie mogą się wzajemnie dopełniać, tworząc harmoniczną całość. Zdają sobie sprawę, że wiedzy zdroworozsądkowej oraz wiedzy naukowej, filozoficznej odpowiadają inne języki, które dokonują konceptualizacji tej samej zastanej rzeczywistości. Myślenie zdroworozsądkowe wyrażane jest w języku potocznym, podczas gdy myśleniu naukowemu odpowiada język naukowy. Te języki często traktowane są jako przeciwstawne względem siebie. Zwolennicy twierdzą, że wiedza zdroworozsądkowa i wiedza naukowa wcale nie ograniczają się tylko do tego, co niesie ze sobą dane doświadczenie. To znaczy, że nauka zajmuje się budowaniem koncepcji czy teorii, opierając się na takich procedurach myślowych, które są zgodne z przyjętymi zasadami oraz regułami proceduralnymi. Jednakże powstają również teorie naukowe odwołujące się do codziennych doświadczeń oraz takie, które starają wyjaśnić znaczenie wiedzy potocznej dla budowania tożsamości człowieka. Źródłem wiedzy potocznej jest doświadczenie, charakterystyczne dla niej jest także generalizowanie i idealizowanie, które są znaczące również dla rozumowania i poznania naukowego. Wiedza potoczna koncentruje się na stawianiu pytań instrumentalnych dotyczących celów praktycznych. Innymi słowy, szuka rozwiązań, jak postępować, jakie działanie podjąć, aby ten cel zrealizować ${ }^{30}$.

Common sense składa się z przekonań, które obowiązują w danej społeczności, i to dzięki nim możliwe staje się uzyskanie porozumienia między jednostkami w odniesieniu do podstawowych kwestii życiowych. To właśnie poznanie zdroworozsądkowe, a nie naukowe, warunkuje to, że dana jednostka potrafi umiejętnie przystosować się do danej grupy społecznej. To znaczy, że wiedza potoczna staje się gwarantem prawidłowego funkcjonowania jednostki we wspólnocie. Inaczej mówiąc, bez wiedzy zdroworozsądkowej niemożliwy staje się proces socjalizacji, który pozwala nam na „bycie w świecie”31.

30 J. Warchala, Kategoria potoczności w języku, Katowice 2003, s. 34.

${ }^{31}$ J. Warchala, Kategoria potoczności w języku, dz. cyt., s. 34-35. 
W myśleniu zdroworozsądkowym, potocznym - podobnie jak w naukowym - funkcjonują określone zasady. Po pierwsze - zasada odwołująca się do generalizacji określonych doświadczeń życiowych. $\mathrm{Na}$ jej podstawie dokonujemy prostego ujęcia występujących w świecie faktów empirycznych. Budujemy więc wiedzę instrumentalną, z której potrafimy korzystać w codziennych życiowych sytuacjach. Poznajemy ten rodzaj wiedzy dzięki swoim rodzicom, otoczeniu społecznemu. Jest ona ważna, gdyż daje nam podstawy do intersubiektywnej komunikacji z innymi. Za drugą $\mathrm{z}$ istotnych zasad wiedzy zdroworozsądkowej należy uznać zasadę odniesienia przyjętych społecznie schematów do rzeczywistości społecznej. Korzystamy z tych schematów w swoim codziennym życiu. Jest to typ wiedzy, w ramach której budowane są modelowe wzorce określonych doświadczeń czy też sytuacji. Zdrowy rozsądek kieruje się również zasadą typizacji. Chodzi w niej o to, że dany obiekt bądź daną sytuację traktujemy jako typową, niczym się niewyróżniającą, ponieważ bardzo często występują one w naszej kulturze. Ważny zatem jest tu kontekst społeczny, a więc to, jaką przyjmujemy wizję świata, zależne jest od tego, w jakim kręgu kulturowym przyszło nam dorastać. Innymi słowy, nasze doświadczenia są w znacznym stopniu podobne do doświadczeń innych, a to oznacza, że jest to wiedza o charakterze intersubiektywnym, którą wspólnie podzielamy z ludźmi wywodzącymi się z tego samego kręgu kulturowego $^{32}$.

Wyróżniamy trzy sfery, które kształtują świadomość społeczną. Pierwsza sfera to tak zwana sfera rzeczywistości obiektywnej, gdzie dochodzi do podejmowania działań przez jednostki. Chodzi o ten typ działań, które są determinowane za pośrednictwem czynników, a także warunków zewnętrznych. Wyrażają one nasze codzienne doświadczenie, jakie zdobywamy, obcując z istniejącymi zjawiskami, które funkcjonują w otaczającej nas rzeczywistości. W drugiej sferze, czyli sferze rzeczywistości intersubiektywnej, są budowane oraz wytwarzane społeczne komunikaty. Istotną zatem rolę pełni komunikacja intersubiektywna, która umożliwia stworzenie wspólnoty poglądów. Inaczej mówiąc, w procesie

${ }^{32}$ J. Warchala, Kategoria potoczności w języku, dz. cyt., s. 34-37. 
komunikacji powstaje ogólny katalog znaczeń obowiązujący w danym kręgu kulturowym. Trzecią sferą kształtującą myślenie potoczne jest sfera rzeczywistości subiektywnej. W ramach tej sfery wyrażamy swoją indywidualną wizję świata, nasze doświadczenia, które składają się na naszą wiedzę potoczną. Dzięki temu możemy dokonać identyfikacji jednostkowych wydarzeń oraz doświadczeń, a to pozwala na ich dalszą weryfikację z przypadkami rozumianymi przez pryzmat ogółu ${ }^{33}$.

\section{Zakończenie}

Analizując odmienne stanowiska odnoszące się do znaczenia coomon sense, skłaniam się ku stanowisku, że wiedza zdroworozsądkowa nie zagraża filozofii. Co, więcej jest nam potrzebna, ponieważ stanowi fundament dla innych form poznawczych, z którymi mamy do czynienia zarówno w życiu codziennym, społecznym, jak i politycznym. Można powiedzieć, że jest ona swego rodzaju „złoty środkiem” w ujęciu arystotelesowskim, czyli umiarem między życiem kontemplacyjnym preferowanym przez filozofów a codziennym życiem w ramach określonego kręgu kulturowego, w którym dokonuje się intersubiektywna komunikacja społeczna.

Zarówno przeciwnicy, jak i zwolennicy common sense mają słuszne spostrzeżenia, które należy brać pod uwagę, dokonując jego analizy. W tym momencie wykażę słabe, jak i mocne strony dwóch opozycyjnych względem siebie obozów, czyli przeciwników oraz zwolenników wiedzy zdroworozsądkowej. W przypadku przeciwników common sense uważam, że ich pogląd, jakoby wiedza zdroworozsądkowa stanowiła zagrożenie dla funkcjonowania sfery politycznej, nie jest do końca trafny. Moim zdaniem specyfika przestrzeni politycznej wymusza i wymaga, aby znalazło się w niej miejsce zarówno dla działań pragmatycznych, które nastawione są na realizację krótkotrwałych celów, jak i miejsce dla działań zorientowanych na realizacje celów długofalowych, które uwzględniają oraz przewidują ich dalekosiężne konsekwencje. To znaczy, że współcześnie władza

${ }^{33}$ J. Warchala, Kategoria potoczności w języku, dz. cyt., s. 32. 
polityczna powinna zdawać sobie sprawę $\mathrm{z}$ tego, że w poszczególnych przypadkach wymaga się od niej szybkiej interwencji, a w niektórych tego, aby najpierw dokonała namysłu, a następnie stworzyła długofalowy plan, by potem konsekwentnie go realizować. Słabą stroną stanowiska przeciwników common sense jest pominięcie jego roli w procesie kształtowania się społecznej świadomości. To właśnie wiedza zdroworozsądkowa stanowi bazę dla budowania tożsamości indywidualnej oraz tożsamości zbiorowej (wspólnotowej). To poznanie zdroworozsądkowe umożliwia nam budowanie więzi międzyludzkich w oparciu o wspólną świadomość społeczną w ramach danego kręgu kulturowego. Dlatego też bez tej formy poznawczej nie możemy utworzyć wspólnoty społecznej, a tym bardziej wspólnoty politycznej. Kolejnym zarzutem względem przeciwników common sense jest ich dogmatyczna postawa w stosunku do pragmatyzmu. Nie można całkowicie demonizować działań opierających się na kategorii użyteczności, albowiem wymiar pragmatyczny jest nieodłącznym elementem życia społecznego. Natomiast słuszne jest ich założenie, że poznanie zmysłowe może zaprowadzić nas do popełniania błędów w procesie poznawczym. Nie możemy do końca zawierzać swoim zmysłom, to znaczy, że wiedza zdroworozsądkowa powinna być weryfikowana przez namysł filozoficzny oraz wiedzę naukową.

W związku z powyższym należy skrytykować u zwolenników common sense przeświadczenie o słuszności poznania zmysłowego, które jest fundamentalne dla wiedzy zdroworozsądkowej. Możemy bowiem naiwnie wierzyć w pozór, to znaczy w to, że coś jest takie, jak przedstawiają nam nasze zmysły, i co w rezultacie w rzeczywistości okaże się zupełnie inne. Tym, co należy docenić u zwolenników common sense, jest docenienie przez nich wpływu zdrowego rozsądku na kształtowanie się tożsamości zarówno w wymiarze jednostkowym, jak i kolektywnym. Jednakże słabą stroną w ich rozważaniach jest gloryfikacja praktycznego wymiaru egzystencji człowieka kosztem sfery duchowej i intelektualnej. Innymi słowy, doświadczenia życiowe są ważnym elementem, ale nie najważniejszym. Należy docenić sferę duchową oraz intelektualną człowieka, bo to ona umożliwia nam osiągnięcie poznania racjonalnego, w którym pojawia się refleksja oraz namysł filozoficzny. 


\section{Bibliografia}

Broszkiewicz P., Charlesa Sandersa Peirce’a koncepcja znaku względem Peirce’owskiego pragmatyzmu, „Słupskie Studia Filozoficzne” 2012 nr 11, s. 191-202.

Cwynar M. K., O potrzebie refleksji filozoficznej w działaniach politycznych, „, O Ф I A” 15 (2015), s. 274-278.

Czerniak S., Gernota Böhmego idea końca ery Baconiańskiej, „Filozofia i Nauka” 1 (2013), s. $35-52$.

Geetz C., Wiedza lokalna. Dalsze eseje z zakresu antropologii interpretatywnej, Kraków 2005.

Grabowska M., Potoczność w obrazie wiary w Boga na podstawie wypowiedzi współczesnych Polaków, „Słowo. Studia językoznawcze” 2014 nr 5, s. 68-81.

Gutowski P., O trzech elementach filozofii Thomasa Reida, „Roczniki Filozoficzne” 58 (2010) nr 1, s. 71-93.

Jaroszewski M. T., Filozofia egzystencji a etyka sytuacyjna Jean Paul Sartre’a, „Etyka” 7 (1970), s. 39-75.

Karpiński A., Kojkoł J., Filozofia, zarys historii, Gdynia 2001.

Kucharski D., „Common sense” jako uzasadnienie Berkeleyowskiej tezy immaterialistycznej, „Studia Philosophiae Christianae” 48 (2012) nr 2, s. 49-63.

Malewska-Szałygin A., Zarys tradycji stosowania pojęcia „wiedza potoczna”, „Etnografia Polska” 39 (1995) z. 1-2, s. 51-63.

Mrzygłód P., Jaka filozofia na dzisiejsze czasy...? Postmodernizm?, „Perspectiva” 11 (2012) nr 2, s. 107-129.

Pobojewska A., Co to znaczy filozofować?, „Analiza i Egzystencja” 15 (2011), s. 99-117.

Rozynek M., Kilka uwag o pojęciu zdrowego rozsądku w perspektywie filozofii politycznej, „Mishellanea” 2004 nr 4, s. 1-12.

Szewczyk-Kowalczyk J., Indywidualne doświadczenie, wspólnotowy sens i zdroworozsądkowa myśl potoczna w kontekście koncepcji „common sense”, „Kultura i Wychowanie” 2011 nr $1245-253$.

Szewczyk-Kowalczyk J., Mistyfikacja codzienności szkolnej, czyli refleksji kilka o „common sense” szkoły, „Studia Pedagogiczne” 64 (2011), s. 73-80.

Warchala J., Kategoria potoczności w języku, Katowice 2003. 


\section{Abstrakt \\ Wady i zalety common sense w wyjaśnianiu i rozumieniu świata społecznego}

$\mathrm{W}$ artykule podejmuję próbę analizy zdrowego rozsądku, czyli tak zwanego common sense. Wskazuję jego wady oraz zalety w perspektywie poznawania świata społecznego. W pierwszej części artykułu koncentruję się na wybranych koncepcjach filozoficznych, które podważają znaczenie myślenia potocznego. Następnie kategorie common sense ujmuję jako zagrożenie dla myśli oraz refleksji politycznej. Natomiast w drugiej części artykułu poświęcam uwagę koncepcjom filozoficznym, które doceniają wpływ wiedzy zdroworozsądkowej na budowanie tożsamości jednostki oraz poznanie człowieka.

\section{Słowa klucze}

common sense, wiedza zdroworozsądkowa, refleksja filozoficzna, refleksja polityczna, tożsamość

\section{Abstract \\ Advantages and Drawbacks of Common Sense in Explaining and Understanding Social World}

The article attempts an analysis of the so called common sense. It points to its advantages and disadvantages for the process of social world cognition. In its first part, it concentrates on selected philosophical concepts that disprove the meaning of informal reasoning. Further, the category of common sense is presented as a threat to political thought and reflection. In its second part, the article concentrates on philosophical concepts that value the influence of practical knowledge on construing identity of an individual and human cognition.

\section{Keywords}

common sense, practical knowledge, philosophical reflection, political reflection, identity 